Louisiana State University

LSU Digital Commons

Faculty Publications

Department of Biological Sciences

10-9-2009

\title{
St. John's Wort inhibits adipocyte differentiation and induces insulin resistance in adipocytes
}

Zhaleh Amini

Louisiana State University

Bryant Boyd

Louisiana State University

Julie Doucet

Louisiana State University

David M. Ribnicky

Rutgers University-New Brunswick

Jacqueline M. Stephens

Louisiana State University

Follow this and additional works at: https://digitalcommons.Isu.edu/biosci_pubs

\section{Recommended Citation}

Amini, Z., Boyd, B., Doucet, J., Ribnicky, D., \& Stephens, J. (2009). St. John's Wort inhibits adipocyte differentiation and induces insulin resistance in adipocytes. Biochemical and Biophysical Research Communications, 388 (1), 146-149. https://doi.org/10.1016/j.bbrc.2009.07.137

This Article is brought to you for free and open access by the Department of Biological Sciences at LSU Digital Commons. It has been accepted for inclusion in Faculty Publications by an authorized administrator of LSU Digital Commons. For more information, please contact ir@lsu.edu. 


\title{
St. John's Wort inhibit adipocyte differentiation and induces insulin resistance in adipocytes
}

\author{
Zhaleh Amini ${ }^{1}$, Bryant Boyd ${ }^{1}$, Julie Doucet ${ }^{1}$, David M. Ribnicky ${ }^{2}$, and Jacqueline $\mathbf{M}$. \\ Stephens ${ }^{1,{ }^{*}}$ \\ ${ }^{1}$ Department of Biological Sciences, Louisiana State University, Baton Rouge, LA 70803 \\ ${ }^{2}$ Rutgers University, New Brunswick, NJ
}

\section{Abstract}

Adipocytes are insulin sensitive cells that play a major role in energy homeostasis. Obesity is the primary disease of fat cells and a major risk factor for the development of Type II diabetes, cardiovascular disease, and metabolic syndrome. Obesity and its related disorders result in dysregulation of the mechanisms that control adipocyte gene expression and function. To identify potential novel therapeutic modulators of adipocytes, we screened 425 botanical extracts for their ability to modulate adipogenesis and insulin sensitivity. We observed that less than $2 \%$ of the extracts had substantial effects on adipocyte differentiation of 3T3-L1 cells. Two of the botanical extracts that inhibited adipogenesis were extracts from St. John's Wort (SJW). Our studies revealed that leaf and flower, but not root, extracts isolated from SJW inhibited adipogenesis as judged by examining PPAR $\gamma$ and adiponectin levels. We also examined the effects of these SJW extracts on insulin sensitivity in mature 3T3-L1 adipocytes. Both leaf and flower extracts isolated from SJW substantially inhibited insulin sensitive glucose uptake. The specificity of the observed effects was demonstrated by showing that treatment with SJW flower extract resulted in a time and dose dependent inhibition of insulin stimulated glucose uptake. SJW is commonly used in the treatment of depression. However, our studies have revealed that SJW may have a negative impact on adipocyte related diseases by limiting differentiation of preadipocytes and significantly inducing insulin resistance in mature fat cells.

\section{Introduction}

The use of herbal supplements is on the rise around the world, but insufficient data exist on the efficacy of most botanical products. Many countries have increased their efforts to subject botanicals to rigorous scientific research. Our laboratory participated in a blinded screening study to evaluate the effects of over four hundred botanical extracts on adipocyte differentiation. We observed that less than $2 \%$ of the extracts had substantial effects on adipocyte differentiation. Two of the botanical extracts that inhibited adipogenesis were extracts from St. John's Wort (SJW). SJW is commonly used in the treatment of depression and a variety of other conditions; however its effects on adipocytes have not been studied.

\footnotetext{
(c) 2009 Elsevier Inc. All rights reserved.

*To whom correspondence should be addressed Louisiana State University, Department of Biological Sciences, 202 Life Sciences Bldg., Baton Rouge, LA 70803, Phone (225)-578-1749, FAX (225)-578-2597, jsteph1@.lsu.edu.

Publisher's Disclaimer: This is a PDF file of an unedited manuscript that has been accepted for publication. As a service to our customers we are providing this early version of the manuscript. The manuscript will undergo copyediting, typesetting, and review of the resulting proof before it is published in its final citable form. Please note that during the production process errors may be discovered which could affect the content, and all legal disclaimers that apply to the journal pertain.
} 
Adipocytes are highly specialized insulin sensitive cells that play a major role in energy homeostasis in vertebrate organisms. Obesity is the primary disease of fat cells and a major risk factor for the development of non-insulin dependent diabetes mellitus (NIDDM), cardiovascular disease, metabolic syndrome and hypertension. Since SJW is readily available and consumed by millions of people and both obesity and diabetes are world-wide epidemics; understanding the effects of SJW on adipocyte development and function is worthwhile. Adipocytes are the primary sites of lipid storage, are insulin sensitive, and secrete endocrine hormones and compounds which alter these properties could be protective or causative of obesity and type II diabetes. Our studies demonstrated that leaf and flower extracts, but not root extracts, from SJW were capable of inhibiting adipocyte differentiation of 3T3-L1 cells. Moreover, these SJW flower and leaf extracts were shown to inhibit insulin sensitive glucose uptake in mature fat cells. In summary, our results suggest that SJW has profound effects on adipocyte development and function.

\section{Materials and Methods}

\section{Materials}

Dulbecco's Modified Eagle's Media (DMEM) was purchased from Invitrogen. Bovine and fetal bovine (FBS) sera were purchased from Hyclone. Both the PPAR $\gamma$ monoclonal antibody and the STAT 5A polyclonal antibody were purchased from Santa Cruz. The adiponectin antibody was a rabbit polyclonal obtained from Affinity Bioreagents. HRPconjugated secondary antibodies were purchased from Jackson Immunoresearch. Enhanced chemiluminescence (ECL) kit was purchased from Pierce. Nitrocellulose was purchased from BioRad. St. John's Wort extracts were prepared by the Rutgers University Botanical Research Center. Briefly, plant samples were air dried and extracted with 80\% ethanol (1:5 $\mathrm{w} / \mathrm{v}$ ) three times, infused each time for $24 \mathrm{~h}$, and evaporated in a rotary evaporator to thick aqueous suspension. The extracts were further dried under vacuum and stored in amber glass vials at $-20^{\circ} \mathrm{C}$. Prior to use, extracts were re-suspended in DMSO.

\section{Cell Culture}

Murine 3T3-L1 preadipocytes were plated and grown to 2 days post confluence in DMEM with $10 \%$ bovine serum. Medium was changed every 48 hours. Cells were induced to differentiate by changing the medium to DMEM containing $10 \%$ fetal bovine serum, 0.5 $\mathrm{mM} 3$-isobutyl-1-methylxanthine, $1 \mu \mathrm{M}$ dexamethasone, and $1.7 \mu \mathrm{M}$ insulin. At this time, cells were treated with a 1000X stock of the botanical extracts suspended in DMSO. Cells were also treated with DMSO alone. After 48 hours this medium was replaced with DMEM supplemented with $10 \%$ FBS and treated again with botanical extracts or vehicle (DMSO).

\section{Preparation of Whole Cell Extracts}

Monolayers of 3T3-L1 preadipocytes or adipocytes were rinsed with phosphate-buffered saline (PBS) and then harvested in a non-denaturing buffer containing $150 \mathrm{mM} \mathrm{NaCl}, 10$ mM Tris, pH 7.4, 1 mM EGTA, 1 mM EDTA, $1 \%$ Triton-X 100, 0.5\% Igepal CA-630 (Nonidet P-40), $1 \mu \mathrm{M}$ PMSF, $1 \mu \mathrm{M}$ pepstatin, 50 trypsin inhibitory milliunits of aprotinin, and $10 \mu \mathrm{M}$ leupeptin, and $2 \mathrm{mM}$ sodium vanadate. Samples were extracted for 30 minutes on ice and centrifuged at $10,000 \times \mathrm{g}$ at $4^{\circ} \mathrm{C}$ for 15 minutes. Supernatants containing whole cell extracts were analyzed for protein content using a BCA kit (Pierce) according to the manufacturer's instructions.

\section{Gel Electrophoresis and Western Blot Analysis}

Proteins were separated in 7.5\% polyacrylamide (acrylamide from National Diagnostics) gels containing sodium dodecyl sulfate (SDS) according to Laemmli [1] and transferred to 
nitrocellulose membrane in $25 \mathrm{mM}$ Tris, $192 \mathrm{mM}$ glycine, and 20\% methanol. Following transfer, the membrane was blocked in $4 \%$ fat-free milk for 1 hour at room temperature. Results were visualized with HRP-conjugated secondary antibodies and enhanced chemiluminescence.

\section{Determination of ${ }^{3} \mathrm{H}$-labeled 2-Deoxyglucose Uptake}

The assay of 2- $\left[{ }^{3} \mathrm{H}\right]$ deoxyglucose was performed as previously described [2]. Prior to the assay, mature 3T3-L1 adipocytes were serum deprived for $2 \mathrm{~h}$ and treated with various doses of botanical extracts for different periods of time. Next, the cells were incubated in the presence or absence of insulin $(10 \mathrm{nM})$ for $10 \mathrm{~min}$. Glucose uptake was initiated by addition of 2- $\left[{ }^{3} \mathrm{H}\right]$ deoxyglucose at a concentration of $0.1 \mathrm{mM}$ 2-deoxyglucose in $1 \mu \mathrm{Ci} 2-\left[{ }^{3} \mathrm{H}\right]$ deoxyglucose in Krebs-Ringer-Hepes buffer and incubated for $3 \mathrm{~min}$ at room temperature. Glucose uptake is reported as $\left[{ }^{3} \mathrm{H}\right]$ radioactivity, corrected for nonspecific diffusion $(5 \mu \mathrm{M}$ cytochalasin B) and normalized to total protein content as determined by BCA analysis. Nonspecific uptake and absorption was always less than $10 \%$ of the total uptake. Uptake measurements were performed in triplicate under conditions where hexose uptake was linear.

\section{Results}

In a blinded study, we screened 425 botanical extracts to examine their ability to modulate adipocyte differentiation of 3T3-L1 cells. We observed that less than $2 \%$ of the extracts had substantial effects on adipocyte differentiation. After the screening was complete and identification of the extracts was unblinded, we noted that two of the botanical extracts that inhibited adipogenesis were extracts from St. John's Wort (SJW). As shown in Figure 1, three extracts from SJW were examined for their ability to inhibit the induction of adipocyte specific proteins such as PPAR $\gamma$ and adiponectin. Extracts from the root (R) of SJW had no effect on adipocyte development, but extracts from the leaves (L) and flowers (F) blocked the induction of PPAR $\gamma$ and adiponectin expression. In addition, the normal induction in STAT5A expression which accompanies differentiation [3] was also inhibited. Botanical extracts obtained from SJW were resuspended in DMSO and diluted 1000 fold into the cell culture media. Vehicle treatment of DMSO had no effect on adipocyte development. In addition, there was no observable cell death (data not shown) and MAPK expression was examined to indicate equivalent levels of protein in each sample.

To assess the specificity of this inhibitory effect, we examined the ability of various doses of the flower extract to modulate adipocyte differentiation. As shown in Figure 2, treatment with a flower extract of SJW resulted in a dose dependent inhibition of adipogenesis as indicated by an inhibition in the induction of PPAR $\gamma$ and adiponectin expression. As indicated in Figure 1, a dose of $50 \mu \mathrm{g} / \mathrm{ml}$ completely blocked the induction of PPAR $\gamma$ and adiponectin. In addition, a dose of $25 \mu \mathrm{g} / \mathrm{ml}$ significantly attenuated the induction of PPAR $\gamma$ and blocked the induction of adiponectin. Treatment with $12 \mu \mathrm{g} / \mathrm{ml}$ did not inhibit the induction of PPAR $\gamma$, but substantially reduced the induction of adiponectin expression. Treatment with the lowest dose of flower extract $(6 \mu \mathrm{g} / \mathrm{ml})$ or treatment with DMSO (V) had no effect on the induction of PPAR $\gamma$ and adiponectin as compared to untreated (CTL) cells. MAPK expression does not change during the differentiation of 3T3-L1 cells and is shown to indicate equivalent levels of protein in each sample.

Because two of the SJW extracts affected adipocyte development, we examined the ability of these SJW extracts to modulate adipocyte function. Fully differentiated 3T3-L1 adipocytes were treated with SJW extracts for 90 minutes and then glucose uptake was examined in the presence and absence of an acute stimulation with insulin. As shown in Figure 3, vehicle (control) treated cells were highly responsive to insulin treatment which 
resulted in a 4.5 fold increase in glucose uptake. None of the SJW extracts had any effect on glucose uptake in the absence of insulin. However, treatment with a leaf or flower extract resulted in a significant inhibition of insulin stimulated glucose uptake. To assess the specificity of these effects, mature 3T3-L1 adipocytes were pretreated overnight with the various doses of SJW flower extract indicated in Figure 4A. These studies revealed a dose dependent inhibition in insulin sensitive glucose uptake. Mature adipocytes were also pretreated for various times with $25 \mu \mathrm{g} / \mathrm{ml}$ flower extract of SJW. After a 1 or 2 hour treatment, there was a substantial inhibition of insulin sensitive glucose uptake. An 18 hour pretreatment consistently resulted in an even greater inhibition of insulin stimulated glucose uptake.

\section{Discussion}

SJW is a common commercially available botanical that is widely used as an over the counter treatment for depression. In a blinded screening study, we observed that extracts obtained from the flower and leaf of SJW, but not the roots, were capable of inhibiting the adipogenesis of murine preadipocytes. Of note, a current hypothesis is that Type 2 diabetes can be viewed as a failure to appropriately expand fat mass in the context of a positive energy balance [4]. In light of this notion, the ability of SJW to inhibit adipogenesis may not be metabolically favorable. Several studies suggest that inhibiting adipocyte development can be a causative factor in the development of insulin resistance [5;6]. In addition to its ability to inhibit adipocyte development, SJW extracts can also have negative effects on mature fat cells. We observed that SJW flower extracts resulted in a time and dose dependent inhibition of insulin stimulated glucose uptake in mature mouse fat cells. Although less insulin sensitive, we also observed that these extracts could inhibit insulin stimulated glucose uptake in cultured human fat cells (data not shown). Based on our in vitro studies, our results suggest that SJW may have some negative effects on adipocyte development and function. There is a substantial body of literature indicating that SJW can interfere with the action of numerous drugs (reviewed in [7]). It is well established that SJW lowers the circulating concentrations and pharmacological effects of a number of drugs and oral contraceptives [8]. Hyperforin, a psychoactive constituent of SJW, has been to shown to potently activate the pregnane $\mathrm{X}$ receptor $[9 ; 10]$ which is known to activate various set of genes that are involved in the metabolism and excretion of drugs [11].

Although our studies on SJW are limited to in vitro observations, there is some data to support a role of SJW in insulin resistance. A recent paper demonstrated that a protein found in SJW can modulate MCP-1 promoter expression and result in increased MCP-1 expression [12]. It is well known that macrophage derived inflammatory mediators are substantially increased in of obesity and Type 2 diabetes in mice and humans [reviewed in 13]. Moreover, MCP-1 has been shown to regulate the infiltration of macrophages into adipose tissue and play a part in insulin resistance [14]. Since SJW has been shown to increase MCP-1 expression [12], it is reasonable to hypothesize that this popular herb may also be capable of inducing insulin resistance in vivo, perhaps via induction of MCP-1. In summary, a screening process to identify botanical extracts that regulated adipocyte development resulted in the observation that extracts from leaf or flower of SJW inhibit adipogenesis and insulin sensitive glucose uptake in fat cells. Obesity and diabetes are world-wide epidemics and SJW is readily available over the counter and consumed by millions of people wide. Overall, our studies suggest that SJW may have a negative impact on adipocyte related diseases by limiting differentiation of preadipocytes and significantly inducing insulin resistance in mature fat cells. 


\section{Acknowledgments}

We are grateful to Pat Arbour-Reily and Ursula A. White for technical assistance and preparation of the manuscript.

This work was supported by pilot project funding from the Pennington Biomedical Botanical Center.

\section{References}

1. Laemmli UK. Cleavage of structural proteins during the assembly of the head of bacteriophage T4. Nature 1970;227:680-685. [PubMed: 5432063]

2. Stephens JM, Pekala PH. Transcriptional repression of the GLUT4 and C/EBP genes in 3T3-L1 adipocytes by tumor necrosis factor-alpha. J Biol Chem 1991;266:21839-21845. [PubMed: 1939208]

3. Stephens JM, Morrison RF, Pilch PF. The expression and regulation of STATs during 3T3-L1 adipocyte differentiation. J Biol Chem 1996;271:10441-10444. [PubMed: 8631837]

4. Gray SL, Vidal-Puig AJ. Adipose tissue expandability in the maintenance of metabolic homeostasis. Nutr Rev 2007;65:S7-12. [PubMed: 17605308]

5. Kim JY, van de WE, Laplante M, Azzara A, Trujillo ME, Hofmann SM, Schraw T, Durand JL, Li H, Li G, Jelicks LA, Mehler MF, Hui DY, Deshaies Y, Shulman GI, Schwartz GJ, Scherer PE. Obesity-associated improvements in metabolic profile through expansion of adipose tissue. J Clin Invest 2007;117:2621-2637. [PubMed: 17717599]

6. Wang NY, Grayburn P, Chen S, Ravazzola M, Orci L, Unger RH. Adipogenic capacity and the susceptibility to type 2 diabetes and metabolic syndrome. Proc Natl Acad Sci U S A 2008;105:6139-6144. [PubMed: 18413598]

7. Kober M, Pohl K, Efferth T. Molecular mechanisms underlying St. John's wort drug interactions. Curr Drug Metab 2008;9:1027-1037. [PubMed: 19075619]

8. Di YM, Li CG, Xue CC, Zhou SF. Clinical drugs that interact with St. John's wort and implication in drug development. Curr Pharm Des 2008;14:1723-1742. [PubMed: 18673195]

9. Wentworth JM, Agostini M, Love J, Schwabe JW, Chatterjee VK. St John's wort, a herbal antidepressant, activates the steroid X receptor. J Endocrinol 2000;166:R11-R16. [PubMed: 10974665]

10. Moore LB, Goodwin B, Jones SA, Wisely GB, Serabjit-Singh CJ, Willson TM, Collins JL, Kliewer SA. St. John's wort induces hepatic drug metabolism through activation of the pregnane X receptor. Proc Natl Acad Sci U S A 2000;97:7500-7502. [PubMed: 10852961]

11. Goodwin B, Redinbo MR, Kliewer SA. Regulation of cyp3a gene transcription by the pregnane $\mathrm{x}$ receptor. Annu Rev Pharmacol Toxicol 2002;42:1-23. [PubMed: 11807162]

12. Mukerjee R, Deshmane SL, Darbinian N, Czernik M, Khalili K, Amini S, Sawaya BE. St. John's Wort protein, p27SJ, regulates the MCP-1 promoter. Mol Immunol 2008;45:4028-4035. [PubMed: 18649942]

13. Ferrante AW Jr. Obesity-induced inflammation: a metabolic dialogue in the language of inflammation. J Intern Med 2007;262:408-414. [PubMed: 17875176]

14. Kanda H, Tateya S, Tamori Y, Kotani K, Hiasa K, Kitazawa R, Kitazawa S, Miyachi H, Maeda S, Egashira K, Kasuga M. MCP-1 contributes to macrophage infiltration into adipose tissue, insulin resistance, and hepatic steatosis in obesity. J Clin Invest 2006;116:1494-1505. [PubMed: $16691291]$ 


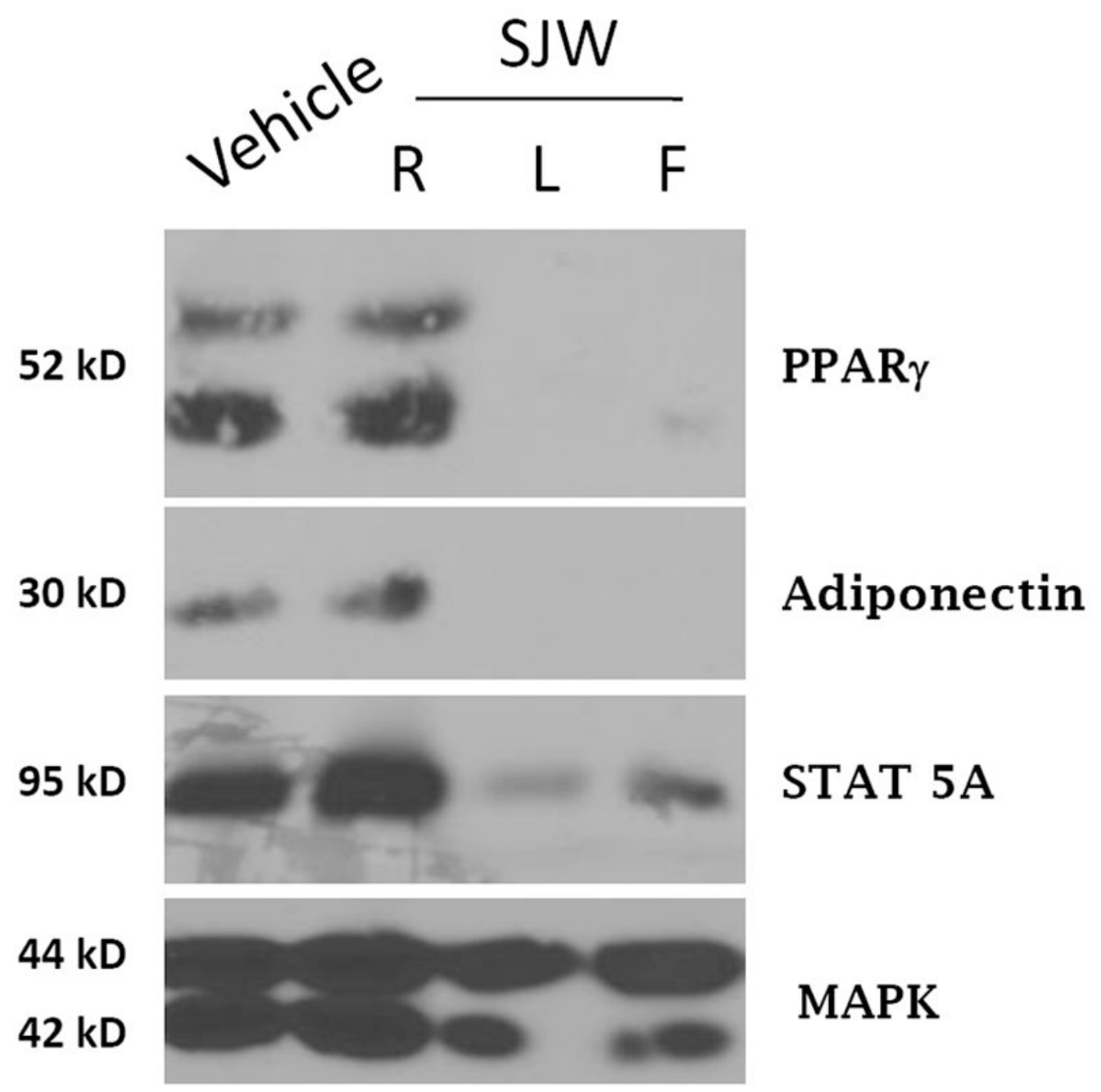

Figure 1. Leaf and Flower extracts from SJW inhibit adipocyte differentiation of 3T3-L1 cells Whole cell extracts were prepared from 3T3-L1 cells one week after they were induced to differentiate with the normal induction cocktail in the presence or absence of $50 \mu \mathrm{g} / \mathrm{ml}$ of SJW extracts obtained from SJW. Cells were also treated with a $1000 \mathrm{X}$ stock of DMSO (vehicle). One hundred ug of each extract was separated by SDS-PAGE, transferred to nitrocellulose, and subjected to Western blot analysis. The detection system was horseradish peroxidase-conjugated secondary antibodies and enhanced chemiluminescence (Pierce). This is a representative experiment independently performed three times. 


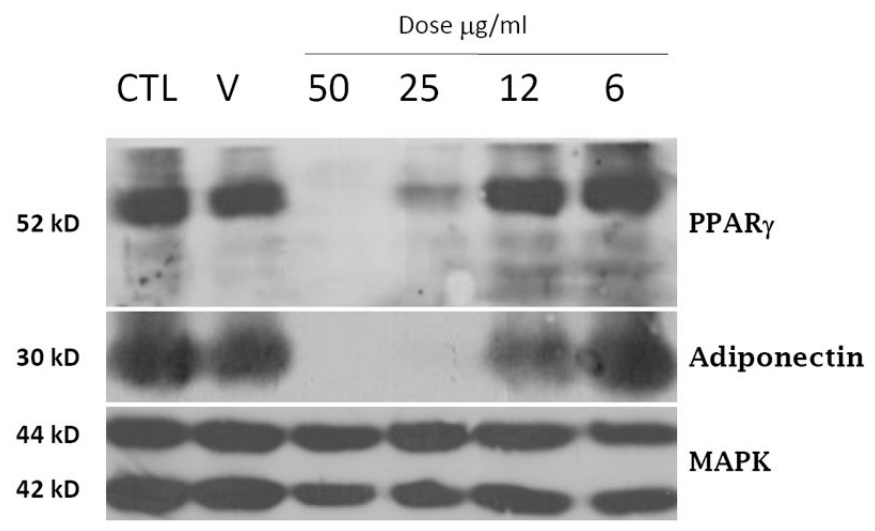

Figure 2. A flower extract from SJW results in a dose dependent inhibition of adipogenesis in 3T3-L1 cells

Whole cell extracts were prepared from 3T3-L1 cells one week after they were induced to differentiate with the normal induction cocktail in the presence of various doses of a SJW flower extract. Cells were also treated with a 1000X stock of DMSO (V). One hundred ug of each extract was separated by SDS-PAGE, transferred to nitrocellulose, and subjected to Western blot analysis. Samples were processed and results were visualized as described in Figure Legend 1. This is a representative experiment independently performed three times. 


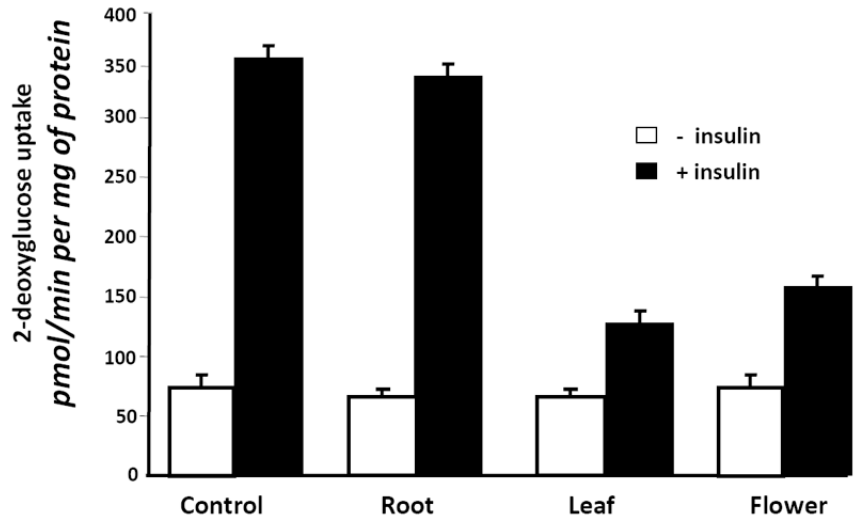

Figure 3. Leaf and Flower, but not root, extracts from SJW induce insulin resistance in fully differentiated 3T3-L1 adipocytes

Fully differentiated 3T3-L1 adipocytes were serum deprived and treated overnight (20 hours) with $25 \mu \mathrm{g} / \mathrm{ml}$ of the indicated SJW extract. After the pretreatment, cells were stimulated with insulin $(10 \mathrm{nM})$ for $10 \mathrm{~min}$. Glucose uptake was initiated by addition of 2$\left[{ }^{3} \mathrm{H}\right]$ deoxyglucose. The glucose uptake values shown represent the mean $+/-\mathrm{S}$.E. of triplicate determinations from four independent experiments. 

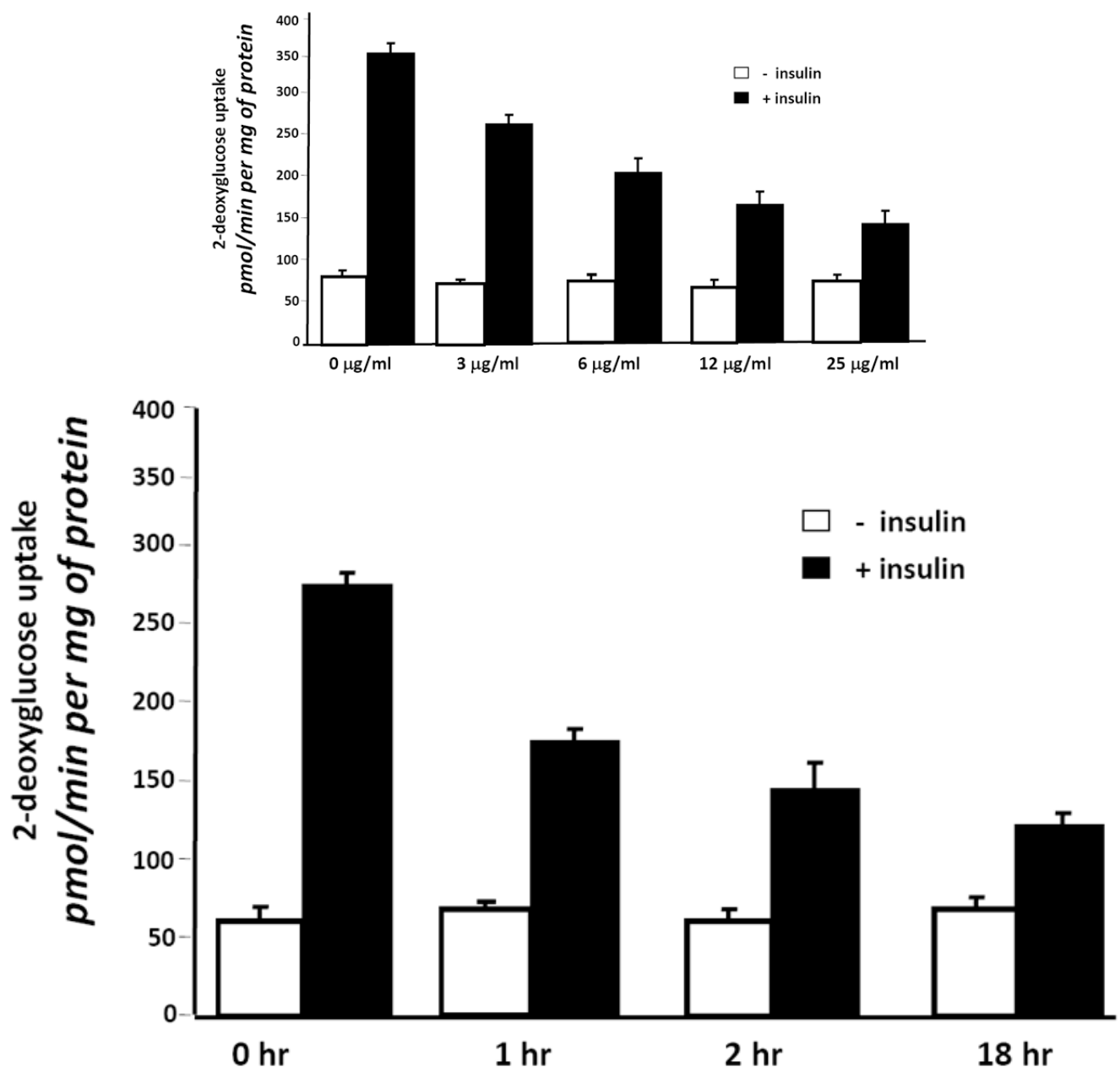

Figure 4. A flower extract of SJW induces insulin resistance in cultured murine adipocytes in a dose and time dependent manner

(A) Fully differentiated 3T3-L1 adipocytes were serum deprived and pretreated for 90 minutes with various doses of a SJW flower extract. (B) Fully differentiated 3T3-L1 adipocytes were serum deprived and pretreated for the indicated times with $25 \mu \mathrm{g} / \mathrm{ml}$ of a SJW flower extract. After the pretreatment, cells were stimulated with insulin $(10 \mathrm{nM})$ for $10 \mathrm{~min}$. Glucose uptake was initiated by addition of $2-\left[{ }^{3} \mathrm{H}\right]$ deoxyglucose. The glucose uptake values shown represent the mean +/- S.E. of triplicate determinations from four independent experiments. 